\title{
Risk of cancer in patients with scleroderma
}

\section{J E Pearson, A J Silman}

\section{Risk of cancer may be slightly increased, but extra screening is not necessary}

$\mathrm{T}$ he first report linking cancer with scleroderma ( $\mathrm{Scl}$ ) was 50 years ago when a case of alveolar cell carcinoma was described. ${ }^{1}$ Since then there have been several further case reports and series linking Scl with cancer at various sites. ${ }^{2}$ The sites of cancer most frequently reported are the lung ${ }^{3}$ and breast $^{5}$ (perhaps reflecting their prevalence in the general population), but cancers at other sites have also been reported. ${ }^{26}$ In this issue of the Annals there is a report of an Australian population study on $\mathrm{Scl}$ and cancer. ${ }^{7}$ The authors showed a doubling in the risk of all cancers over an average six year follow up period, with the lung being the site at greatest risk. It is thus timely to consider all the evidence suggesting this association is real and then explore some of the possible underlying explanations.

\section{IS THERE AN ASSOCIATION?}

It is necessary to compare the incidence of cancer occurring in patients with Scl with that occurring in an appropriately matched general population sample, typically derived from regional or national cancer registers. Studies, such as the current report from Australia, are enhanced when they attempt to include all cases arising in a population to minimise the likelihood of a severity bias. Table 1 summarises the results of a number of such main population studies. In these studies the risk of cancer is expressed as standardised incidence ratios (SIRs) (equivalent to relative risks, which are calculated by dividing the number of observed cases of cancer in patients with Scl by the number of expected cases, allowing for the age and sex of the patients, in the general population occurring during the same period of follow up). Though the early studies reported no association, ${ }^{815}$ most of the more recent studies have found an increased risk (table 1), typically around twofold. However, a recent large study from the USA, ${ }^{14}$ although in abstract form only, reported no increased risk and this lack of consistency is a cause for caution. The lung is the site with the reported greatest risk with relative risks of up to $16.5 .^{3}$ Consistent with the case reports there is also a frequently reported trend for an increase in breast cancer, which is not always statistically significant. $^{7}$
There are few studies that have looked at the role of potential risk factors in Scl and cancer. A recent Japanese study ${ }^{13}$ suggested that anticentromere antibody positivity (linked with limited $\mathrm{Scl}$ ) is a significant risk factor. Consistent with these observations is that the presence of antitopoisomerase I has been associated with cancer in patients with Scl only. ${ }^{16}$ In support of this the latest Australian study found that patients with diffuse involvement were at greater risk than those with limited cutaneous disease. This difference was modest and perhaps explains why others found no significant difference between disease subsets. Older age ( $>50$ years) at diagnosis of $\mathrm{Scl}$, not surprisingly, was a significant risk factor, although interestingly neither the sex of the patient nor smoking differed significantly. ${ }^{10}$

\section{POSSIBLE EXPLANATIONS}

If there is an increased association between Scl and cancer it is useful to consider the possible explanations. In brief, one disease may increase the risk of the other either as a direct complication or as a result of the treatment given. Alternatively, the two disorders may share common risk factors.

\section{Scl as a risk factor for malignancy}

Diseases such as Scl which are associated with lung damage have been linked to an increased risk of cancer compared with the general population. ${ }^{17}$ Pulmonary fibrosis resulting from non-Scl causes, such as silicosis, is a well recognised risk factor for malignancy. ${ }^{18}$ Thus it has been suggested that Scl related pulmonary fibrosis is a risk factor for subsequent lung cancer. In support of this a study from the USA showed that pulmonary fibrosis was present in $62 \%$ of the

Table 1 Epidemiological studies on the risk of cancer in Scl

\begin{tabular}{|c|c|c|c|c|c|c|c|c|}
\hline \multirow[b]{2}{*}{ Ref } & \multirow[b]{2}{*}{ Year } & \multirow[b]{2}{*}{ Country } & \multirow{2}{*}{$\begin{array}{l}\text { Mean } \\
\text { follow up } \\
\text { years }\end{array}$} & \multirow{2}{*}{$\begin{array}{l}\text { No of cases } \\
\text { of } \mathrm{Scl}\end{array}$} & \multicolumn{3}{|l|}{ All cancers, SIR $(95 \% \mathrm{CI})$} & \multirow[b]{2}{*}{ Sites of risk } \\
\hline & & & & & All & Male & Female & \\
\hline 8 & 1982 & Australia & 3.3 & 27 & 6.45 (0.78 to 23.29$)$ & $\begin{array}{l}8.33 \\
(0.21 \text { to } 46.28)\end{array}$ & $\begin{array}{l}5.26 \\
(0.13 \text { to } 29.22)\end{array}$ & No significant risk found \\
\hline 9 & 1985 & USA & 4.3 & 262 & $1.81^{*}$ & $2.46^{*}$ & $1.58^{*}$ & Lung \\
\hline 10 & 1993 & Canada & 4.6 & 248 & $7.90^{*}$ & & & $\begin{array}{l}\text { Lung } \\
\text { Breast }\end{array}$ \\
\hline $11 \dagger$ & 1993 & Sweden & 5.1 & 233 & $2.4(1.5$ to 3.6$)$ & $1.8^{*}$ & $2.9^{*}$ & $\begin{array}{l}\text { Lung } \\
\text { Non-Hodgkin's lymphoma }\end{array}$ \\
\hline $12 \dagger$ & 1995 & Sweden & & 917 & 1.5 (1.2 to 1.9 ) & & & $\begin{array}{l}\text { Lung } \\
\text { Non-melanoma skin cancers } \\
\text { Primary liver cancer } \\
\text { Increase in haematopoietic } \\
\text { cancers }\end{array}$ \\
\hline 13 & 2000 & Japan & 6 & 43 & $5.1 \quad(1.7$ to 10.8$)$ & & & \\
\hline 14 & 2000 & USA & & 490 & $0.75(0.45$ to 1.18$)$ & $\begin{array}{l}1.14 \\
(0.37 \text { to } 2.66)\end{array}$ & $\begin{array}{l}0.77 \\
(0.42 \text { to } 1.29)\end{array}$ & $\begin{array}{l}\text { Lung } \\
\text { Breast }\end{array}$ \\
\hline 7 & 2003 & $\begin{array}{l}\text { South } \\
\text { Australia }\end{array}$ & $\begin{array}{l}5.5 \text { (male) } \\
6.1 \text { (female) }\end{array}$ & 441 & $\begin{array}{l}1.99(1.46 \text { to } 2.65) \\
\text { Diffuse } S c l 2.73 \\
(1.31 \text { to } 5.02) \\
\text { Limited } \mathrm{Scl} 1.85 \\
\text { (1.23 to } 2.68)\end{array}$ & & & Lung \\
\hline
\end{tabular}

${ }^{*} \mathrm{Cl}$ s not presented; $†$ there is some overlap between these two studies. 
patients with Scl who developed lung cancer compared with $28 \%$ of those who remained cancer free. ${ }^{9}$ Others have also reported that lung cancer was associated with Scl related pulmonary fibrosis. ${ }^{10}$ However, a retrospective study from France of 123 cases of lung cancer in Scl subjects identified no clinical, immunological, or histological, including pulmonary fibrosis, predictors. ${ }^{19}$

\section{"Most studies, but not all, show increased risk of lung cancer in Scl"}

An alternative hypothesis is that immunosuppressive drugs used to treat $\mathrm{Scl}$ may predispose patients to cancer. There have been no studies to assess this, but there is evidence that immunosuppression, for example in those who have had a kidney transplant, may increase the risk of subsequent malignancy. ${ }^{20}$ However, although sites recorded include the lung and breast, they are not the sites at greatest risk. ${ }^{21}$

\section{Malignancy as a risk factor for Scl}

Although there is no evidence that cancer itself increases the risk of Scl, there is reported evidence that some of the treatments used in cancer induce Scl or Scl-like reactions. Thus there have been reports of Scl-like skin after radiation therapy for breast cancer. ${ }^{22}{ }^{23}$ In addition, there have been case reports of an Scl-like illness after the use of anticancer drugs, including docetaxel, ${ }^{24}$ paclitaxel, ${ }^{25}$ a combination of uracil and tegafur, ${ }^{26}$ bleomycin ${ }^{27}$ and carboplatin chemotherapy. ${ }^{28}$ A recent case report has reported the development of Raynaud's phenomenon in a child after chemotherapy. ${ }^{29}$ By contrast there have also been reports of Scl remission during chemotherapy. ${ }^{30}$

\section{"Some cancer treatments induce scleroderma"}

An interesting hypothesis relates to the possibility that breast malignancy leads to a silicone implant, the latter causing an increased risk of Scl. Despite several case reports describing a link between silicone implants and $\mathrm{Scl}^{31} 32$ several large epidemiological studies have not shown any association between implants and Scl. ${ }^{33}{ }^{34}$

\section{Shared risk factors}

The other explanation is that there are shared risk factors, either genetic or environmental, for the two diseases. There is an increased risk of cancer in first degree relatives of patients with Scl, suggesting that there may be a common genetic/environmental link. ${ }^{35}$ Other indirect evidence suggesting a shared environmental link comes from a prospective
American study which found a high incidence of tongue and oral malignancies, raising the possibility that an ingested carcinogenic compound may possibly initiate $\mathrm{Scl}^{36}$ Smoking is not considered a risk factor for $\mathrm{Scl}$, which would have been one obvious explanation for the increased number of lung cancers. By contrast, coal miners have an increased risk of both disorders, perhaps mediated through pulmonary fibrosis as suggested above.

Other environmental agents such as exposure to organic solvents has been linked independently to both cancer $^{37}$ and $\mathrm{Scl}^{38}$ and may be of relevance, but there are no data on this. Scl has been associated with chromosomal damage/ breakage, ${ }^{39}$ and this may also possibly be linked to a role in cancer development.

\section{SUMMARY}

The data suggesting a link between Scl and cancer are not overwhelming, but there is probably a modest increase in risk, particularly of lung cancer, in patients with diffuse disease and associated pulmonary fibrosis. By contrast, there does not seem to be a convincing and biologically coherent case for a nonspecific increased risk of malignancy in patients with Scl. Given that the lung status of patients with diffuse disease is already regularly monitored, these conclusions do not suggest any additional screening is necessary.

Ann Rheum Dis 2003;62:697-699

\section{Authors' affiliations}

J E Pearson, A J Silman, ARC Epidemiology Unit, School of Epidemiology and Health Sciences, University of Manchester, Room 2.514, Stopford Building, Oxford Road, Manchester M13 9PT, UK

Correspondence to: Professor A Silman; alan.silman@man.ac.uk

\section{REFERENCES}

1 Zatuchni J, Campbell WN, Zarafonetis CJD. Pulmonary fibrosis and terminal bronchiolar carcinoma in scleroderma. Cancer 1953;6: 1 147-58

2 Bielefeld P, Meyer P, Caillot D, Dalac S, Camus $\mathrm{P}$, Tavernier $\mathrm{C}$, et al. Systemic sclerosis and cancer: 21 new cases and review of literature. Rev Med Interne 1996;17:810-13.

3 Peters-Golden M, Wise RA, Hochberg M, Stevens MB, Wigley FM. Incidence of lung cancer in systemic sclerosis. J Rheumatol 1985; 12:1136-9.

4 Talbott JH, Barrocas M. Carcinoma of the lung in progressive systemic sclerosis: a tabular review of the literature and a detailed report of the roentgenographic changes in two cases. Semin Arthritis Rheum 1980;9:191-217.

5 Forbes AM, Woodrow JC, Verbov JL, Graham RM. Carcinoma of breast and scleroderma: four further cases and a literature review. $\mathrm{Br} J$ Rheumatol 1989;28:65-9

6 Mattingly PC, Mowat AG. Rapidly progressive scleroderma associated with carcinoma of the oesophagus. Ann Rheum Dis 1979;38:177-8.
7 Hill CL, Nguyen A-M, Roder D,

Roberts-Thomson P. Risk of cancer in patients with scleroderma: a population based cohort study. Ann Rheum Dis 2003;62:728-31.

8 Black KA, Zilko PJ, Dawkins RL. Cancer in connective tissue disease. Arthritis Rheum 1982;25:1130-3.

9 Roumm AD, Medsger TA. Cancer and systemic sclerosis - an epidemiologic-study. Arthritis Rheum 1985;28:1336-40.

10 Abu-Shakra M, Guillemin F, Lee P. Cancer in systemic sclerosis. Arthritis Rheum 1993;36:460-4

11 Rosenthal AK, McLaughlin JK, Linet MS, Persson I. Scleroderma and malignancy: an epidemiological study. Ann Rheum Dis 1993:52:531-3.

12 Rosenthal AK, McLaughlin JK, Gridley G, Nyren $O$. Incidence of cancer among patients with systemic sclerosis. Cancer 1995;76:910-14.

13 Higuchi $M$, Horiuchi T, Ishibashi N, Yoshizawa S, Niho Y, Nagasawa K. Anticentromere antibody as a risk factor for cancer in patients with systemic sclerosis. Clin Rheumatol 2000; 19:123-6.

14 Chatteriee S, Severson RK, Weiss LK, Kau TY, Mayes MD. Risk of malignancy in scleroderma [abstract]. Arthritis Rheum 2000;43 (suppl):S315.

15 Duncan SC, Winkelmann RK. Cancer and scleroderma. Arch Dermatol 1979; 1 15:950-5.

16 Rothfield N, Kurtzman S, Vazques-Abad D, Charron C, Daniels L, Greenberg B. Association of anti-topoisomerase I with cancer. Arthritis Rheum 1992;35:724.

17 Bouros D, Hatzakis K, Labrakis H, Zeibecoglou K. Association of malignancy with diseases causing interstitial pulmonary changes. Chest 2002;121:1278-89.

18 Finkelstein MM. Silica, silicosis, and lung cancer: a risk assessment. Am J Ind Med 2000;38:8-18.

19 Kyndt X, Hebbar M, Queyrel V, Hachulla E, Hatron PY, Devulder B. Systemic sclerosis and malignancy: assessment of risk factors associated with the development of cancer in 123 patients with systemic sclerosis. Rev Med Interne 1997; 18:528-32.

20 Tremblay F, Fernandes M, Habbab F, Edwardes MDD, Loertscher R, Meterissian S. Malignancy after renal transplantation: incidence and role of type of immunosuppression. Ann Surg Onco 2002;9:785-8

21 Montagnino G, Lorca E, Tarantino A, Bencini $P$, Aroldi A, Cesana B, et al. Cancer incidence in 854 kidney transplant recipients from a single institution: comparison with normal population and with patients under dialytic treatment. Clin Transplant 1996;10:461-9.

22 Abu-Shakra M, Lee P. Exaggerated fibrosis in patients with systemic sclerosis (scleroderma) following radiation therapy. Rheumatol 1993;20:1601-3.

23 Davis DA, Cohen PR, McNeese MD, Duvic $M$. Localized scleroderma in breast cancer patients treated with supervoltage external beam radiation: radiation port scleroderma. $J$ Am Acad Dermatol 1996;35:923-7.

24 Hassett G, Harnett P, Manolios N. Scleroderma in association with the use of docetaxel (taxotere) for breast cancer. Clin Exp Rheumatol 2001;19:197-200.

25 De Angelis R, Bugatti L, Cerioni A, Del Medico P, Filosa G. Diffuse scleroderma occurring after the use of paclitaxel for ovarian cancer. Clin Rheumatol 2003;22:49-52.

26 Kono $T$, Ishii $M$, Negoro $N$, Taniguchi S Scleroderma-like reaction induced by uracil-tegafur (UFT), a second-generation anticancer agent. J Am Acad Dermatol 2000:42:519-20.

27 Kerr LD, Spiera H. Scleroderma in association with the use of bleomycin: a report of 3 cases. J Rheumatol 1992;19:294-6.

28 Karim M, Vaux E, Davies DR, Mason PD. Renal failure due to scleroderma with thrombotic microangiopathy developing in a 
woman treated with carboplatin for ovarian cancer. Clin Nephrol 2002;58:384-8

29 Emir S, Kutluk T, Topaloglu R, Bakkaloglu A, Buyukpamukcu M. Scleroderma in a child after chemotherapy for cancer. Clin Exp Rheumatol 2001;19:221-3.

30 Comer M, Harvey AR. Remission of scleroderma during chemotherapy for lymphoma. Ann Rheum Dis 1992:51:998-1000.

31 Spiera H, Kerr LD. Scleroderma following silicone implantation - a cumulative experience of 11 cases. J Rheumatol 1993;20:958-61.

32 Sahn EE, Garen PD, Silver RM, Maize JC.

Scleroderma following augmentation

mammoplasty - report of a case and review of the literature. Arch Dermatol 1990; 126: 1 198-202.

33 Janowsky EC, Kupper LL, Hulka BS Meta-analyses of the relation between silicone breast implants and the risk of connective-tissue diseases. $N$ Engl I Med 2000;342:781-90

34 Hochberg MC, Perlmutter DL, Medsger TA, Nguyen K, Steen V, Weisman MH, et al. Lack of association between augmentation mammoplasty and systemic sclerosis (scleroderma). Arthritis Rheum 1996;39:1125-31.

35 Sakkas LI, Moore DF, Akritidis NC. Cance in families with systemic sclerosis. Am J Med Sci 1995;310:223-5.
36 Jimenez SA. A prospective study of the association of malignancy with systemic sclerosis [abstract]. Arthritis Rheum 1999;42(suppl): S1 89.

37 Lynge E, Anttila A, Hemminki K. Organic solvents and cancer. Cancer Causes Control 1997:8:406-19

38 Diot E, Lesire V, Guilmot JL, Metzger MD, Pilore R, Rogier S, et al. Systemic sclerosis and occupational risk factors: a case-control and occupational risk factors: a case-control
study. Occup Environ Med 2002;59:545-9.

39 Rittner G, Schwanitz G, Baur MP, Black CM Welsh KI, Kuhnl P, et al.' Family studies in scleroderma (systemic-sclerosis) demonstrating an HLA-linked increased chromosomal breakage rate in cultured lymphocytes. Hum Genet 1988:81:64-70.

We are delighted to announce this forthcoming conference in Auckland, New Zealand.

The themes of the 3rd Asia Pacific Forum on Quality Improvement in Health Care are:

- Agenda for quality: Improving equity in health care delivery

- Improving safety

- Leadership for improvement

- Measuring quality and benchmarking for change

- Evidence based knowledge and education for quality improvement

- Improving health systems

- Patient/consumer centred quality improvement

Presented to you by the BM Publishing Group (London, UK) and Institute for Healthcare Improvement (Boston, USA), supported by the New Zealand Ministry of Health, ACC, and Standards New Zealand.

For more information about the Forum or to register contact: quality@bma.org.uk or go to:

www.quality.bmipg.com

Tel: +44 (0)207383 $6409 \quad$ Fax: +44 (0)20 73836869 